\title{
Parachuted into Parliament: Candidate Nomination, Appointed Candidates, and Legislative Roles in Canada
}

\author{
ROYCE KOOP* \& AMANDA BITTNER** \\ ${ }^{*}$ School of Public Policy, Simon Fraser University, Canada; **Department of Political Science, \\ Memorial University, Canada
}

\begin{abstract}
Does a candidate's pathway to parliament affect subsequent legislative roles and behavior? Party candidate nomination processes in Canada are very decentralized, with responsibility for candidate selection allocated to the local constituency associations. However, candidates may also secure a nomination by being "parachuted" into a constituency: appointed by the party leader as the candidate who will stand for the party in the general election. This practice is most common in the Liberal Party of Canada, and as such we study this party's candidates in the six most recent elections (between 1993 and 2008) in order to explore both (a) the characteristics of parachuted and locally nominated MPs; and (b) the legislative consequences of parachuting candidates into constituencies. We find that party leaders are using the power of appointment to recruit both star candidates and women into the House of Commons, but that appointed candidates from each of these groups serve very different roles in Parliament. We find a strong link between nomination method and subsequent legislative roles and activities: parachuted candidates are much more likely to serve in high-profile legislative positions while locally nominated candidates are more likely to engage in low-profile legislative activities. The process by which candidates come to stand for election, we argue, directly affects the nature of representation by Members of Parliament in the legislature, and has implications for the study of candidate nomination and legislative roles in parties in other democracies.
\end{abstract}

The methods used to nominate candidates are important indicators of the distribution of power within political parties. As Schattschneider (1942: 101) argues, "the nominating process has become the crucial process of the party. He who can make the nominations is the owner of the party." From a comparative perspective, the candidate nomination processes of Canadian parties are very decentralized, with party constituency associations allowing local members to select prospective candidates (Rahat, 2007: 163). While the local nomination race is normal practice, there is an alternate path to Parliament for MPs: appointment to the party nomination by the

Correspondence Address: Dr. Royce Koop, School of Public Policy, Simon Fraser University, Vancouver, BC, V6B5K3 Canada. Email: royce_koop@sfu.ca 
leader. "Parachuting" candidates into constituencies means that those candidates can bypass local nomination races and therefore run under the party banner without winning the consent or support of local party members. ${ }^{1}$

The prevalence of parachuted candidates has increased in the last two decades, but the consequences of appointments have not yet been examined (but see Mishler, 1978). In this article, we explore the characteristics of appointed candidates and the legislative consequences of parachuting candidates into party nominations. We first construct profiles of locally nominated and parachuted candidates. Second, following studies of the legislative priorities of representatives elected under mixedmember electoral systems (e.g. Mcleay \& Vowles, 2007), we compare the legislative activities of parachuted MPs to those that won local nomination contests in the traditional manner. Specifically, we explore the extent to which locally nominated and parachuted candidates differ in their legislative roles and activities in parliament. We find that there are significant differences in both the characteristics and legislative behaviors of parachuted and locally nominated candidates. The legislative activities of these MPs fall into two distinctive legislative domains: high profile for parachuted candidates and low profile for nominated candidates.

This article contributes to two key debates in the study of political parties. First, it touches on a prominent theme in the literature that points to the centralization of power in the hands of leaders of both parties and governments (e.g. Michels, 1915; Savoie, 1999). We demonstrate that appointments enhance the power of party leaders not only to select candidates, but also to shape the legislative organization and thus the public face of the party. Second, this article fits squarely into an important and growing literature that addresses the extent to which parties are open to and representative of women and other traditionally marginalized groups (e.g. Caul, 2001). We demonstrate that successive Liberal party leaders have used their appointment powers to enhance the representation of these groups in the party caucus, but that appointments have not necessarily translated into high-profile legislative positions.

We first review the relevant literature on the parliamentary organizations of political parties and how electoral institutions and candidate selection methods influence legislative behavior. Second, we describe the nomination and appointment processes in Canada's Liberal Party. We then turn to addressing our research questions, and conclude by discussing the democratic implications of party leaders' decisions to parachute candidates into ridings, and the comparative implications of our analysis. ${ }^{2}$

\section{The Impact of Institutions on Legislative Behavior}

Party elites and particularly leaders face a range of incentives in determining who fills high-profile positions in the parties' legislative organizations. Many studies of the US Congress work from a "gains from trade" perspective in which the incentives facing individual members are taken into account in determining the party's legislative organizations (for example, see Shepsle, 1978). However, party leaders are concerned primarily with the success of the party as a whole, so legislative organization is likely 
to reflect the collective interests of the party (Cox \& McCubbins, 1993). In Canada, the composition of parties' parliamentary organizations - which are determined by the party leader - are of utmost importance since the lack of any extra-parliamentary party organization ensures that those MPs awarded high-profile legislative positions, particularly in the cabinet and shadow cabinet, constitute the national public face of the party (Sayers, 1999: 216, 219).

Party leaders must therefore place competent MPs in high-profile legislative positions while also ensuring that the public face presented by the party is electorally advantageous. To ensure stability and durability, prime ministers tend to appoint former leadership contenders and MPs with previous ministerial experience (Kerby, 2009: 607-608). However, a range of representative concerns also informs the composition of the federal cabinet. As White (2001: 19) argues, "In Canada ... what has been termed the 'representational imperative' has been elevated to the status of political dogma. All important ... regions, ethnic, linguistic and cultural groups must have their representatives at the cabinet table." The classic (and outdated) formulation of this imperative is "The Three R-s": race, religion, and region (Rogers, 1933: 1). To these can be added newer equity concerns, so the prime minister must also consider sex and ethnicity in making high-profile legislative appointments (for an example from the Canadian provinces, see Studlar \& Moncrief, 1997). Making such appointments to high-profile legislative positions in order to ensure an attractive public face for the party is all the more difficult given the low proportion of female MPs in the Canadian House of Commons (Trimble \& Arscott, 2003).

Individual MPs engage in legislative activities in response to a range of incentives. Research across institutional contexts suggests that the manner in which legislators are selected and/or elected affects both their priorities and the types of activities they engage in once in office. Three types of institutional incentives emerge from past research. First, candidates tend to focus on representing those who they feel have a role to play in deciding their political futures. Second, candidates engage in institution-appropriate campaign activities. Third, certain types of political systems lead to higher levels of internal party cohesion than others, thus influencing the nature of legislative debate and other activities.

Mcleay and Vowles (2007) find that constituency and list MPs under New Zealand's mixed-member proportional (MMP) electoral system focus on different aspects of the job while in office. MPs that are elected in constituencies tend to be slightly more focused on local activities and spend more time in contact with constituents. In contrast, MPs elected on party lists tend to be more involved with the representation of descriptively defined minority groups. Research in Scotland, Wales, and Germany also suggests that list representatives seek out non-geographic constituencies such as interest groups or other minorities to represent because they lack a clear geographic constituency to represent in the legislature (Lundberg, 2006). And Judge and Ilonszki (1995) find that Hungarian list MPs tend to identify primarily with the party and nation, while constituency MPs tend to focus on and identify primarily with local interests. 
Lundberg (2006) notes that list MPs are better able to shirk the local vote, while constituency MPs tend to focus more of their attention on constituency service in order to increase their likelihood of re-election. He also finds that constituency MPs are more likely to engage in pork-barrel politics, as are constituency representatives in Germany, since these legislators spend more time than list MPs seeking out funding initiatives to benefit local projects (also see Lancaster \& Patterson, 1990). Crisp et al. (2004) demonstrate that pork-barreling is more common in systems with single member districts because candidates hope to demonstrate that they are strong advocates of their districts in the legislature, particularly when working on a bill's passage either in the House or behind the scenes. They find that legislators often introduce bills that are aimed at targeting their constituencies in hopes of re-election. Representatives can positively influence their chances of re-election by adapting their legislative activities to the incentives embedded in the electoral system.

Comparatively high turnover rates in Canadian elections suggest that MPs can do little in parliament to assist in future re-election campaigns (Matland \& Studlar, 2004: 90-91). Nevertheless, Canadian backbench MPs do engage in institution-appropriate behaviors designed to benefit them, including (1) introducing private members' bills (PMBs) in order to develop the image of an effective legislator (Blidook, 2010) and (2) asking questions in Question Period that reflect the interests of their constituencies in order to cultivate a reputation for policy responsiveness (Soroka et al., 2009). However, facing institutional barriers to legislative initiatives including comparatively strong party discipline (Malloy, 2003: 117-120), MPs also place considerable emphasis on constituency service in the hope of constructing a local "personal vote" (Docherty, 1997). Docherty reports that MPs engage in these service behaviors despite their uncertainty that doing so returns electoral dividends in re-election campaigns (1997: 173). The electoral system constitutes an institutional context shaping these legislative behaviors of representatives, with MPs adapting their legislative activities in response to institutional incentives.

The incentives set up by elected members' institutional environments influence not only legislative activity, but have an important impact on campaign activity as well. Mitchell (2000: 345) suggests that electoral systems in which representatives are elected based on their positions on party lists lead politicians to spend their time currying favor with party elites rather than raising money from a wider base of supporters. Strom (1997) similarly suggests that party-focused systems encourage candidates to act in ways that satisfy party requirements - and especially party elites - whereas locally controlled selection processes create an incentive structure in which pleasing the local constituency is a priority. Similarly, Hazan (1999) finds that the adoption of primaries into the Israeli PR system has weakened the link between candidates and parties in Israel, as candidates can no longer depend on the party organization for their nominations. The cohesiveness and influence of parties has as a result diminished, and conflict between the legislative and executive branches has increased. 
Hix (2004: 196) furthers the notion that the selectorate matters, with his suggestion that without the need to appeal to a specific constituency, members have little incentive to break ranks with the party in parliament and will be more likely to toe the party line and reinforce party platforms and positions. The extent to which electoral institutions influence the allegiances of legislators may also have an important impact on the nature of legislative debate and activities. Environments in which electoral success is based on individuals' positions within the party may leave legislators less likely to engage in "individualistic" activities (such as introducing PMBs) and instead more likely to engage in "group" activities (such as committee membership). The opposite may be true in institutional environments that encourage legislators to stand out and stand up for their constituencies.

\section{Candidate Nominations in Canada}

Canadian parties have always been characterized by very decentralized candidate selection methods. In order to run under the party banner, candidates must first win the approval of the local constituency association, which organizes and oversees nomination races. These local nomination campaigns culminate in a vote of the entire local party membership. Carty (2002) argues that this local right to select personnel to staff public office is enumerated in a "franchise bargain" between the party in central office and the parties in the ridings. In return for the right to select candidates, constituency associations provide leaders with the freedom to formulate party policy in their capacity as elite brokers.

Decentralized candidate nomination processes do not, however, preclude interference on the part of the party's national office. Prior to the 1972 national election, the Canada Elections Act was amended to require the party leader's approval of each candidate. The result is that party leaders may simply refuse to sign the nomination papers of prospective candidates. Since this is a blunt measure, party officials may also discourage undesirable candidates in advance by suggesting that the leader will not sign their nomination papers even if they win the local contest (Cross, 2004: 55).

Candidates may also have to cope with interference on the part of their local constituency association executives, which are tasked with organizing nomination races. While executives are expected to organize contests in an impartial manner, there is significant potential for interference, particularly on the part of executive presidents (Koop, 2010: 897-898). Executives may even punish nominated candidates after they are successful by, for example, withholding local resources (Carty \& Eagles, 2005: 50-51).

Party leaders' power to parachute candidates represents a qualitative step beyond such interference. Following several divisive nomination battles during the 1980 s and the selection of Jean Chrétien as party leader in 1990, the party constitution was amended to give the leader control over local nominations (Koehn, 1998). The result was that Chrétien and subsequent leaders were able to pre-empt local nomination contests and appoint candidates with little or even no input from local members. 
This power has been used sparingly. But when party leaders have appointed candidates, we suggest that it has been for three reasons: (1) to increase the representation of women and other groups, (2) to appoint star candidates, and (3) to protect incumbents from local challenges.

One argument in favor of central control of nominations is that the leader is in a good position to appoint women and members of other traditionally marginalized groups (Matland \& Studlar, 1996). The nomination race appears to be the crucial obstacle to the election of women to the House of Commons (Erickson, 1998); indeed, Cheng and Tavits (2011) argue that male-dominated constituency associations may be an even greater barrier to the nomination of women than previously thought (also see Tremblay \& Pelletier, 2001). The result is that central appointment may be essential to increasing the diversity of the candidates fielded by the party. We accordingly refer to candidates that are appointed for this reason as diversity candidates.

Leaders have also appointed star candidates in order to spare these candidates from having to contest local nomination races (Cross, 2004: 60). From the perspective of the party leader, stars benefit the party as a whole to the extent that they deserve to skip local nomination contests (see Sayers, 1999: 83). Paul Martin (Liberal party leader from 2003-2006), for example, appointed David Emerson as candidate in a Vancouver constituency given Emerson's prior professional experience and public profile.

Leaders may also appoint incumbent MPs as candidates. This occurs if the leader values a particular MP who is unable to withstand a local nomination challenge. Prior to the 1993 campaign, for example, Chrétien foiled the ambitions of nomination challengers by re-appointing two incumbent MPs who could not hope to win their respective nomination contests (Koehn, 1998: 68). In an interview with an MP who benefitted from the leader's power in a similar context, the MP noted the hopelessness of his situation and argued that nomination challenges make it impossible for MPs to be effective legislators while in Ottawa. By protecting this incumbent MP from a renomination challenge, the party leader allowed him to refocus on his legislative and representational roles rather than on the renomination challenge in his riding. Accordingly, we refer to these appointed candidates as protected candidates.

The result of leaders' use of the appointment power is that there are now two potential paths to Parliament in the Liberal Party. First, the majority of candidates must win a locally organized nomination race in order to run under the party banner in the ensuing election. Second, a relatively small number of candidates are parachuted into a constituency as the party candidate. We examine the impact of the nomination process in the Liberal Party specifically because it is the party that has made use of this power most often. In our initial assessment of the nomination processes in the three major Canadian parties over this time period (the Conservative Party, the New Democratic Party, and the Liberal Party), a very small number of candidates were appointed by the other two parties, providing little additional data to work with. The result is that our analysis is confined to one of Canada's major political parties. Our selection of the Liberal Party in recent elections also allows us to 


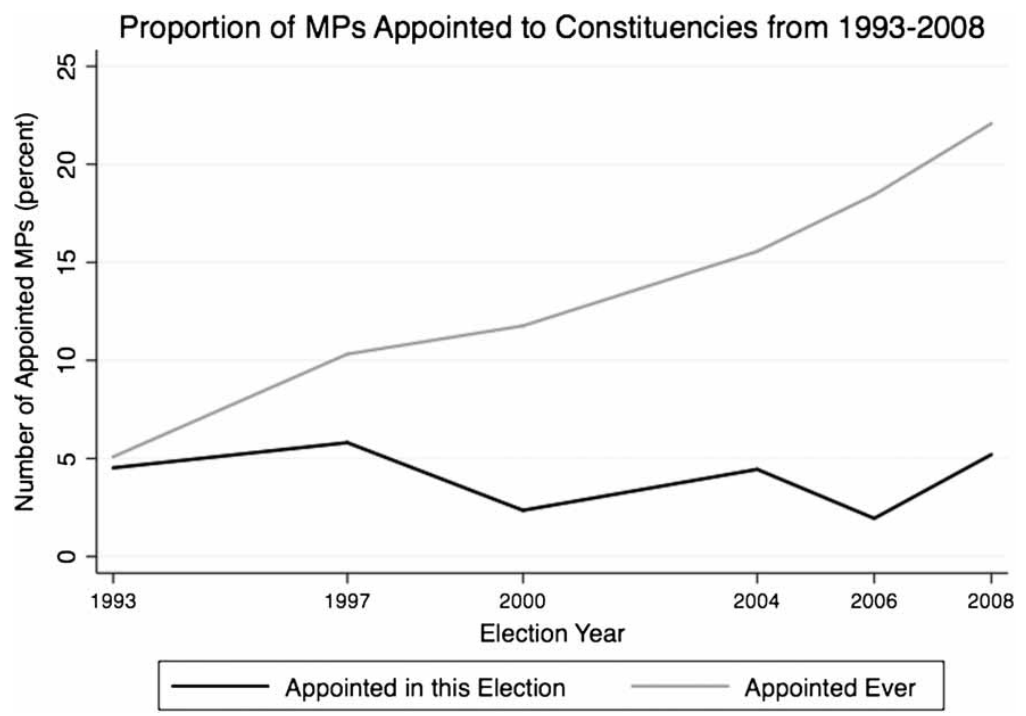

Figure 1. Proportion of MPs appointed to constituencies from 1993 to 2008 .

observe what types of candidates are appointed and the legislative roles of appointed candidates when the party is in both government and opposition.

Figure 1 summarizes the proportion of the Liberal caucus that was made up of appointed candidates following each of the six most recent national elections (between 1993 and 2008). These proportions are presented in two ways. First, Figure 1 presents the proportion of caucus members that were appointed in each election. Second, the figure also shows the proportion of caucus members who were appointed at some point in the past, typically in their first run for elected office.

The number of successful appointed candidates in each election is relatively small. Only eight appointed candidates were elected to parliament in the 1993 election (five were unsuccessful). By 2008, that number had fallen to three. The smaller overall size of the Liberal caucus following the 2008 election meant that the proportion of successful appointed candidates was similar to 1993. While the most recent election saw a significant drop in newly parachuted candidates, the cumulative effect of three separate party leaders appointing candidates over the 15 -year period is that the proportion of MPs who were originally appointed as candidates has steadily grown. In 1993, only 5\% of the Liberal caucus consisted of appointed candidates. By 2008, that proportion had grown to $19 \%$ - roughly one in five Liberal MPs elected in 2008 had commenced their careers or been helped by the leader at some point by parachuting into a local constituency and bypassing the traditional nomination process. Most of these MPs had in fact been appointed by Chrétien or Martin (the first two leaders in this time period) but had since been re-elected, in some cases several times. 
The result is that the Liberal caucus can be understood as consisting of two groups. The first includes the approximately $80 \%$ of MPs who have won local nomination contests in the traditional manner, in order to make their ways to parliament. The second, a smaller, more elite group, consists of MPs who were given the right to contest elected office as a Liberal candidate by the party leader rather than by their local constituency associations. The question is whether the different experiences of these two types of MPs are related to their legislative activities.

\section{Data and Analysis}

In order to assess the impact of the dual paths to parliament on the legislative roles and activities of MPs, we collected data on each Liberal MP elected from 1993 to 2008, as well as collecting data on each Liberal candidate from 1997 to 2008. Finding information about candidates who lost the election prior to 1997 was very difficult, given the drastically lower web presence of candidates at that time. We collected demographic data (including the candidates' sex, immigrant and visible minority status, and previous experience at municipal and provincial levels of government), and information about the election contest itself (vote share and margin of victory in the riding). We also coded candidates for "star" status in each previous election campaign. To do so, we searched the LexisNexis database for each candidate's name in 22 major Canadian newspapers six months prior to each national election. Candidates were coded as stars if they were referred to as such (or as "star candidates") in at least one of these newspaper stories.

We also recorded high-profile legislative roles and low-profile legislative activities. The former consists of appointments to cabinet, shadow cabinet, and ministries of state. The latter includes parliamentary committee activities (including committee memberships and the holding of committee or sub-committee chairs and vicechairs), and the introduction of Private Members' Business (PMB), motions, and statements made in the House of Commons. ${ }^{3}$ These are all important legislative activities, and understanding who does this work is key to understanding the effects of the nomination and appointment process.

In combination, these data provide us with the opportunity to address our two research questions. First, who are leaders parachuting into ridings? Is the leader's appointment power being used to balance existing gaps in representation, contributing to a more diverse and representative House of Commons? If so, we should expect to see higher numbers of women, immigrants, and visible minorities amongst those who have been parachuted into ridings. Or is the power of appointment being used for other purposes, such as the recruitment of star candidates? We also explore the extent to which appointments were made in order to recruit candidates with prior experience in political office at the provincial or municipal levels. While such experience typically designates candidate as "quality candidates" in the American literature (e.g. Berkman \& Eisenstein, 1999), studies of career paths in Canada demonstrate that national MPs tend not to be recruited from provincial legislatures, leading in part to our understanding of Canadian MPs as legislative "amateurs" (Studlar 
et al., 2000: 95-98). Nevertheless, Barrie and Gibbins (1989) suggest that those MPs with sub-national experience have an advantage in terms of appointments to highprofile legislative roles. We test for the possibility the leaders are using their appointment power to recruit such candidates for high-profile positions.

Second, we sought to determine whether the manner in which MPs attain the right to run for their parties - either through leader appointment or by winning a local nomination - influences the types of legislative roles they play once in office. Are parachuted and nominated candidates the same once in the House of Commons, or do they play distinctive legislative roles?

We expect that parachuted candidates are more likely to be appointed by party leaders to high-profile legislative roles. This is because the qualities that lead party leaders to appoint candidates in the first place are also qualities that might convince the prime minister to include appointed members in high-profile legislative roles. Candidates that are parachuted into a riding as a result of their "star" attributes are likely to be appointed to these roles because of their talents. In addition, some parachuted candidates run for office only with the party leader's promise that they will subsequently be appointed to high-profile positions (Docherty, 1997: 106). Further, intuitively it makes sense that candidates appointed in order to enhance the diversity of the House of Commons are also more likely to make it into cabinet since the prime minister must also consider balance and diversity when crafting a cabinet or shadow cabinet. Thus if diversity candidates are parachuted into ridings, we should expect to see them in high-profile legislative roles as well.

In contrast to the high-profile roles we expect to be played by parachuted MPs, we hypothesize that locally nominated MPs (those who win their candidacy in the traditional manner) are more likely to play low-profile legislative roles. Intuitively, committee work might seem more attractive to MPs contesting local nominations and entering politics on their own than it would to stars recruited by the prime minister. Moreover, the high-profile legislative work of many parachuted candidates means that they will be able to point to a record of accomplishment to their constituents; in contrast, nominated MPs turn to committee work and introducing PMBs, motions, and statements in order to demonstrate some degree of legislative accomplishment to voters in their ridings.

\section{Profile of Parachuted and Nominated Candidates}

Understanding who it is that party leaders are choosing to parachute into constituencies is important because this information can provide us with greater insight into why they may have been selected. Figure 2 provides some sense of the background and characteristics of candidates from both nomination paths. The graph compares demographic and background characteristics of candidates running in federal campaigns from 1997 to the 2008, distinguishing between parachuted and locally nominated candidates. 


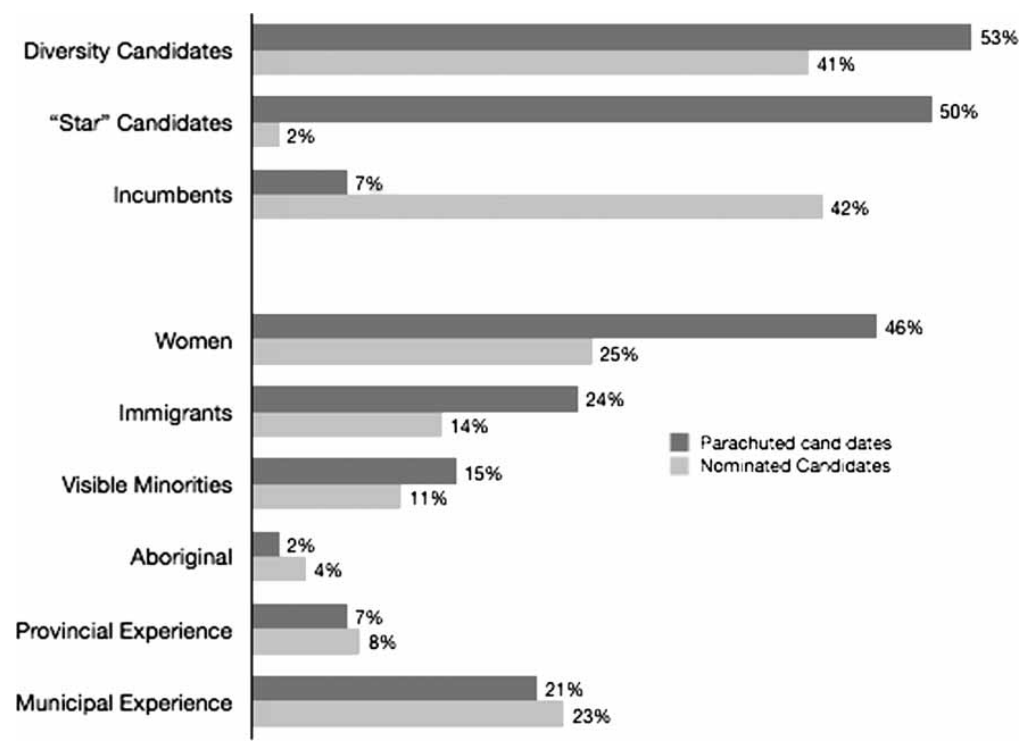

Figure 2. Profiles of parachuted and nominated candidates, 1997-2008.

What is immediately clear is that those candidates who were appointed look different from those who were not. Nearly half of all appointed candidates are women, compared with one quarter $(25 \%)$ of non-appointed candidates. Among appointed candidates, $15 \%$ are visible minorities, compared with $11 \%$ of traditional nomination winners. Nearly one quarter of parachuted candidates are immigrants (24\%), compared with only $14 \%$ of nomination winners. There is little difference in whether appointed and locally nominated candidates are Aboriginal, as only $2 \%$ of appointed candidates are Aboriginal, compared with $4 \%$ for all others. A much higher percentage of star candidates are appointed by party leaders: $50 \%$ of parachuted candidates are considered stars by major national media, while only $2 \%$ of locally nominated candidates are considered stars.

There is also a small contingent of protected candidates, as 7\% of parachuted candidates were incumbents when they were appointed. These are the incumbent MPs who are protected from renomination challenges in their ridings. The major story for incumbents is not, however, one of protection: $42 \%$ of traditional nomination winners are incumbents, suggesting that for the most part, they do not have difficulty retaining their seats. This number goes up even further if we look at candidates who win the election: $76 \%$ of traditional nomination winners who win a seat in the House of Commons are incumbents. The data confirm the importance of incumbency in Canadian elections.

The appointment of quality candidates - those with prior experience at the provincial or municipal levels - appears to be less of a concern for party leaders. Prior municipal and provincial experience is about the same regardless of whether a 
candidate is parachuted into a riding or nominated in the traditional way. This suggests that party leaders are not generally using their appointment powers to bring "quality" candidates into the party caucus. This is not particularly surprising, since candidates with previous experience in provincial and municipal politics are typically well suited to win traditional nomination races.

Taken as a whole, 50\% of parachuted candidates between 1997 and 2008 are star candidates, while $53 \%$ of parachuted candidates are diversity candidates - that is, they are women, immigrants, of visible minority groups, or Aboriginal peoples. Party leaders have clearly used the appointment power to recruit both star and diversity candidates into the party caucus. These patterns suggest that the party leadership is indeed attempting to shape the nature of representation in the House of Commons, and is doing so by shielding some candidates from the traditional local nomination races that might otherwise be an impediment to their success. While the results presented in Figure 2 reflect simple bivariate analyses, these patterns are also confirmed by more sophisticated multivariate statistics. Table 1 displays the results.

Table 1. Factors affecting parachuted status

\begin{tabular}{lc}
\hline & Parachuted in current election \\
\hline Woman & $\mathbf{0 . 9 7 3}$ \\
& $(0.375)$ \\
Immigrant & 1.030 \\
& $(0.560)$ \\
Aboriginal & -0.526 \\
Visible minority & $(0.929)$ \\
& 0.450 \\
Provincial experience & $(0.550)$ \\
& -0.287 \\
Municipal experience & $(0.658)$ \\
Star candidate & 0.302 \\
Incumbent & $(0.436)$ \\
& $\mathbf{4 . 5 5 8}$ \\
Observations & $(0.552)$ \\
\end{tabular}

Notes: Logistical Regression Models: Coefficients Reported (robust standard errors in parentheses, clustered on each individual candidate).

Coefficients in bold significant at $5 \%$ or better.

Fixed effects (dummy variables for each election year) included in the model, results omitted. 
We ran a logistical regression model with parachuted status as the dependent variable, and both sex and "star" status had a significant impact on whether or not an individual was parachuted into a riding. Women were more likely than men to be appointed by the party leader (coefficient of 0.974), as were star candidates (coefficient of 4.558). The other "diversity" categories did not have a significant impact on appointment status, nor did prior experience. Incumbents were less likely to be appointed by the leader (coefficient of -2.402). The data suggest - broadly - that leaders are opting to use the power of appointment primarily to recruit and protect star candidates, although ensuring a greater presence of women in the legislature is also a factor.

In fact, this protection appears to be working. In an effort to determine the impact of being appointed on electoral success, we regressed candidates' vote share on appointment status as well as other demographic characteristics of candidates. As Table 2 indicates, having been parachuted in the past into a riding leads to nearly an 18 percentage point increase in a candidate's vote share. This is increase is about the same that which comes from incumbency status and, given the importance of incumbency in Canadian elections (Eagles, 2004), this is a substantial boost. Star candidates also tend fare better than others, with an increase in vote share of approximately 6 percentage points. Provincial experience is also a boon for candidates, leading to a 2.5 percentage point increase in vote share.

The success of parachuted candidates in subsequent elections is not insubstantial, and accounts for much of the growth in the number of individuals who have been parachuted ever as a proportion of members of the House of Commons that was seen in Figure 1. Of those who were parachuted in 1993, three quarters were re-elected in 1997, 63\% were re-elected in 2000, 50\% were re-elected in 2004 , $25 \%$ were re-elected in 2006, and $13 \%$ were re-elected in the most recent 2008 election. ${ }^{4}$ This demonstrates the potential longevity of candidates, as does the pattern of parachutee success from 1997 onward: 100\% were re-elected in 2000, $70 \%$ were re-elected in 2004, $60 \%$ were re-elected in 2006, and $40 \%$ were re-elected in 2008. Generally speaking, most MPs (54\%) who were parachuted in at some point in the past are still sitting in the House of Commons.

The decline over time reflects the fact that some candidates opted not to run in subsequent elections, as well as the Liberal Party's move from government to opposition status in 2006 and 2008. Of parachutees who are no longer in the legislature, $30 \%$ retired, while $17 \%$ were defeated in a subsequent election. The corresponding numbers for MPs who won their nominations in the traditional manner are somewhat different: $29 \%$ retired, while $39 \%$ were defeated in a subsequent election. The other major difference in career exit paths of the two types of candidates is that traditionally nominated candidates experience other exits in addition to defeat or retirement: two were removed from caucus, just under $3 \%$ lost a subsequent nomination race, and a few left caucus, passed away, defected to another party, or were appointed to the senate. Previously parachuted MPs are either sitting in the House, or else have since retired or were defeated in a subsequent election. The other exit strategies have not (to date) applied to them. 
Table 2. Factors affecting electoral success (as measured by vote share)

\begin{tabular}{|c|c|}
\hline & Vote share \\
\hline Appointed in this election & $\begin{array}{c}1.135 \\
(6.018)\end{array}$ \\
\hline Appointed ever & $\begin{array}{c}\mathbf{1 7 . 7 0 3} \\
(6.695)\end{array}$ \\
\hline Woman & $\begin{array}{r}-1.029 \\
(0.772)\end{array}$ \\
\hline Immigrant & $\begin{array}{c}1.306 \\
(1.342)\end{array}$ \\
\hline Aboriginal & $\begin{array}{c}0.365 \\
(2.276)\end{array}$ \\
\hline Visible minority & $\begin{array}{r}-1.597 \\
(1.584)\end{array}$ \\
\hline Provincial experience & $\begin{array}{c}\mathbf{2 . 4 9 9} \\
(1.198)\end{array}$ \\
\hline Municipal experience & $\begin{array}{c}1.337 \\
(0.809)\end{array}$ \\
\hline Star candidate & $\begin{array}{c}\mathbf{6 . 0 5 4} \\
(2.254)\end{array}$ \\
\hline Incumbent & $\begin{array}{c}\mathbf{1 8 . 2 7 2} \\
(0.641)\end{array}$ \\
\hline \multicolumn{2}{|l|}{ Combinations of variables } \\
\hline Appointed woman & $\begin{array}{l}13.623 \\
(6.576)\end{array}$ \\
\hline Appointed visible minority & $\begin{array}{l}12.517 \\
(6.415)\end{array}$ \\
\hline Appointed incumbent & $\begin{array}{c}9.685 \\
(2.512)\end{array}$ \\
\hline Appointed star candidate & $\begin{array}{c}8.808 \\
(7.229)\end{array}$ \\
\hline Observations & 1,668 \\
\hline
\end{tabular}

Notes: Ordinary Least Squares Regression Models: Coefficients Reported (robust standard errors in parentheses, clustered on each individual candidate).

Coefficients in bold significant at $5 \%$ or better.

Fixed effects (dummy variables for each election year) included in the model, results omitted "Combinations of variables" (in grey) reflect linear combination of appointment status with interacted variables (e.g. appointed ever + appointed"woman) using "lincom" command in STATA, to allow for easier interpretation of interactions. 


\section{Legislative Roles and Activities}

Once elected to the House of Commons, are all MPs the same, regardless of how they became the party's candidate in their riding? Or does the nomination process have an impact on their legislative roles and activities? We expect there to be a difference in the activities of legislators depending on the process by which they became candidates. Appointees are expected to be parachuted into higher offices in much the

Table 3. Impact of appointment status on high-profile legislative activity

\begin{tabular}{|c|c|c|c|}
\hline & Cabinet & Shadow & Minister of State \\
\hline Appointed ever & $\begin{array}{c}\mathbf{3 . 0 7 1} \\
(1.107)\end{array}$ & $\begin{array}{c}3.057 \\
(1.932)\end{array}$ & $\begin{array}{c}4.152 \\
(2.203)\end{array}$ \\
\hline Appointed in this election & $\begin{array}{r}-0.674 \\
(0.970)\end{array}$ & $\begin{array}{r}-\mathbf{4 . 4 2 4} \\
(2.204)\end{array}$ & $\begin{array}{r}-0.359 \\
(1.917)\end{array}$ \\
\hline Woman & $\begin{array}{c}0.044 \\
(0.293)\end{array}$ & $\begin{array}{c}0.520 \\
(0.447)\end{array}$ & $\begin{array}{c}0.023 \\
(0.444)\end{array}$ \\
\hline Visible minority & $\begin{array}{r}-1.093 \\
(0.601)\end{array}$ & $\begin{array}{c}0.035 \\
(0.486)\end{array}$ & $\begin{array}{c}\mathbf{1 . 5 5 7} \\
(0.447)\end{array}$ \\
\hline Vote Share & $\begin{array}{c}0.194 \\
(0.256)\end{array}$ & $\begin{array}{r}-0.071 \\
(0.334)\end{array}$ & $\begin{array}{r}-0.205 \\
(0.371)\end{array}$ \\
\hline Incumbent & $\begin{array}{c}\mathbf{1 . 0 4 4} \\
(0.334)\end{array}$ & $\begin{array}{r}-0.257 \\
(0.498)\end{array}$ & $\begin{array}{c}0.569 \\
(0.493)\end{array}$ \\
\hline Star candidate & $\begin{array}{c}\mathbf{2 . 4 3 7} \\
(0.525)\end{array}$ & $\begin{array}{c}3.378 \\
(2.397)\end{array}$ & $\begin{array}{c}0.258 \\
(0.900)\end{array}$ \\
\hline \multicolumn{4}{|l|}{ Combinations of variables } \\
\hline Appointed woman & $\begin{array}{c}1.672 \\
(1.033)\end{array}$ & $\begin{array}{c}\mathbf{4 . 4 0 7} \\
(2.028)\end{array}$ & $\begin{array}{c}1.119 \\
(2.118)\end{array}$ \\
\hline Appointed visible minority & $\begin{array}{c}2.389 \\
(1.457)\end{array}$ & $\begin{array}{c}4.786 \\
(2.862)\end{array}$ & $\begin{array}{c}0.559 \\
(1.897)\end{array}$ \\
\hline Appointed incumbent & $\begin{array}{c}\mathbf{1 . 7 0 3} \\
(0.495)\end{array}$ & $\begin{array}{c}0.768 \\
(0.552)\end{array}$ & $\begin{array}{c}1.352 \\
(0.738)\end{array}$ \\
\hline Appointed star candidate & $\begin{array}{c}1.844 \\
(1.295)\end{array}$ & $\begin{array}{c}2.634 \\
(2.932)\end{array}$ & $\begin{array}{c}2.063 \\
(2.318)\end{array}$ \\
\hline Observations & 817 & 817 & 817 \\
\hline
\end{tabular}

Notes: Logistical Regression Models: Coefficients Reported (robust standard errors in parentheses, clustered on each individual Member of Parliament).

Coefficients in bold significant at $5 \%$ or better.

Fixed effects (dummy variables for each election year) included in the model, results omitted "Combinations of variables" (in grey) reflect linear combination of appointment status with interacted variables (e.g. appointed ever + appointed"woman) using "lincom" command in STATA, to allow for easier interpretation of interactions. 
same way they were parachuted into their ridings, whereas locally nominated candidates are expected to participate in low-profile legislative activities.

For the most part, our expectations are borne out. Table 3 provides the results of a series of logistical regression analyses where various high-profile legislative activities were regressed on appointment status and other demographic and explanatory variables. ${ }^{5}$ All dependent variables are binary, and coded as "1" if a Member of Parliament performed the activity and " 0 " if she/he did not (regardless of how many times she/he may have done so). The table reports coefficients and robust standard errors. The lower half of the table (shaded in grey) reflects the linear combination of appointment status with the interacted variables, rather than simply listing the interaction coefficients, in order to facilitate interpretation of the interaction of parachuted status with other variables of interest.

As Table 3 indicates, there is a clear and strong relationship between having been parachuted into a riding and being placed in cabinet. Appointed candidates are substantially more likely to sit in cabinet than those candidates that were locally nominated (coefficient of 3.071). This variable has a larger impact on propensity to be appointed to cabinet than all other variables examined, including incumbency status or "star" status. Incumbent MPs who had been appointed in the past were also more likely to be given a cabinet post (coefficient of 1.703). ${ }^{6}$

The relationships between visible minority status, candidate appointments, and high-profile legislative positions are also very suggestive. Members of visible minority groups who are locally nominated are more likely than non-visible minority MPs to be given Minister of State positions (coefficient of 1.557). However, visible minority status does not lead to cabinet or shadow cabinet positions, and parachuted MPs of visible minority status are not more likely to take on high profile positions. Women who had been parachuted in the past were more likely to be given shadow cabinet positions, indicating that opposition status has led the Liberal Party to "promote" more women than it did when the party was in government. These data suggest that while members of visible minority groups and women are more likely to be among parachuted candidates than locally selected nominees (as shown in Figure 2), they are still less likely to be appointed to cabinet.

Table 4 extends the analysis further, and examines the extent to which locally nominated candidates are more likely to engage in low-profile activities. For ease of interpretation, we flipped the independent variables related to appointment status in order to isolate the impact of not being appointed (but rather, winning a traditional nomination race prior to election). Thus we recoded the variable so that 1 reflected MPs who won a nomination while 0 reflected MPs who were appointed. We also interacted this "new" variable with other demographic variables in the model. As Table 4 illustrates, non-appointed MPs are much more likely to engage in low-profile legislative activities. ${ }^{7}$

Locally selected nominees are much more likely to make statements in the House of Commons (coefficient of 2.307), than are parachuted candidates. There does appear to be a time lag of sorts, however, as those who won the nomination in the most recent election were less likely to introduce private members' business 
Table 4. Impact of appointment status on low-profile legislative activity

\begin{tabular}{|c|c|c|c|c|c|c|}
\hline & PMB & Motions & Statements & $\begin{array}{l}\text { Committee } \\
\text { chair }\end{array}$ & $\begin{array}{l}\text { Subcommittee } \\
\text { chair }\end{array}$ & $\begin{array}{c}\text { Committee } \\
\text { member }\end{array}$ \\
\hline Nomination winner & $\begin{array}{l}1.060 \\
(0.838)\end{array}$ & $\begin{array}{c}0.951 \\
(1.341)\end{array}$ & $\begin{array}{l}\mathbf{2 . 3 0 7} \\
(0.874)\end{array}$ & $\begin{array}{l}0.121 \\
(1.074)\end{array}$ & $\begin{array}{l}\mathbf{1 5 . 5 7 3} \\
(0.938)^{* *}\end{array}$ & $\begin{array}{l}\mathbf{1 . 6 5 5} \\
(0.810)^{*}\end{array}$ \\
\hline $\begin{array}{l}\text { Nominee in recent } \\
\text { election }\end{array}$ & $\begin{array}{r}-\mathbf{1 . 4 3 3} \\
(0.582)\end{array}$ & $\begin{array}{r}-1.397 \\
(0.914)\end{array}$ & $\begin{array}{r}-0.570 \\
(0.552)\end{array}$ & $\begin{array}{l}0.105 \\
(0.773)\end{array}$ & $\begin{array}{r}-0.235 \\
(0.854)\end{array}$ & $\begin{array}{r}-0.878 \\
(0.521)\end{array}$ \\
\hline Woman & $\begin{array}{r}-0.514 \\
(0.762)\end{array}$ & $\begin{array}{r}-0.444 \\
(0.716)\end{array}$ & $\begin{array}{c}2.184 \\
(1.193)\end{array}$ & $\begin{array}{r}-0.456 \\
(0.721)\end{array}$ & $\begin{array}{c}0.011 \\
(0.946)\end{array}$ & $\begin{array}{l}1.872 \\
(0.963)\end{array}$ \\
\hline Visible minority & $\begin{array}{l}1.148 \\
(0.726)\end{array}$ & $\begin{array}{c}0.424 \\
(1.015)\end{array}$ & $\begin{array}{l}0.827 \\
(0.769)\end{array}$ & $\begin{array}{r}-\mathbf{1 . 0 8 7} \\
(0.523)\end{array}$ & $\begin{array}{r}-1.422 \\
(0.956)\end{array}$ & $\begin{array}{c}-0.668 \\
(1.107)\end{array}$ \\
\hline Vote share & $\begin{array}{c}0.066 \\
(0.171)\end{array}$ & $\begin{array}{c}0.346 \\
(0.210)\end{array}$ & $\begin{array}{c}0.300 \\
(0.282)\end{array}$ & $\begin{array}{l}\mathbf{0 . 3 9 6} \\
(0.197)\end{array}$ & $\begin{array}{c}0.351 \\
(0.218)\end{array}$ & $\begin{array}{c}0.254 \\
(0.318)\end{array}$ \\
\hline Incumbent & $\begin{array}{r}-0.218 \\
(0.803)\end{array}$ & $\begin{array}{c}1.717 \\
(1.031)\end{array}$ & $\begin{array}{c}0.864 \\
(0.555)\end{array}$ & $\begin{array}{l}1.185 \\
(0.907)\end{array}$ & $\begin{array}{l}\mathbf{1 6 . 0 3 0} \\
(0.976)\end{array}$ & $\begin{array}{c}-0.123 \\
(0.644)\end{array}$ \\
\hline Star candidate & $\begin{array}{r}-\mathbf{1 4 . 8 8 0} \\
(0.713)\end{array}$ & $\begin{array}{c}0.082 \\
(0.808)\end{array}$ & $\begin{array}{c}0.602 \\
(0.603)\end{array}$ & $\begin{array}{r}-0.657 \\
(1.142)\end{array}$ & $\begin{array}{r}-\mathbf{1 4 . 2 7 2} \\
(0.846)\end{array}$ & $\begin{array}{c}-0.403 \\
(1.225)\end{array}$ \\
\hline Cabinet member & $\begin{array}{r}-\mathbf{2 . 0 0 2} \\
(0.498)\end{array}$ & $\begin{array}{r}-\mathbf{1 . 8 9 0} \\
(0.619)\end{array}$ & $\begin{array}{r}-\mathbf{3 . 6 8 8} \\
(0.325)\end{array}$ & $\begin{array}{r}-\mathbf{2 . 7 1 8} \\
(0.489)\end{array}$ & $\begin{array}{r}-\mathbf{2 . 5 2 7} \\
(0.611)\end{array}$ & $\begin{array}{r}-\mathbf{3 . 7 3 2} \\
(0.362)\end{array}$ \\
\hline $\begin{array}{l}\text { Shadow cabinet } \\
\text { member }\end{array}$ & $\begin{array}{c}0.451 \\
(0.713)\end{array}$ & $\begin{array}{c}0.490 \\
(0.808)\end{array}$ & $\begin{array}{c}0.615 \\
(0.603)\end{array}$ & $\begin{array}{c}-0.781 \\
(1.142)\end{array}$ & $\begin{array}{r}-0.480 \\
(0.846)\end{array}$ & $\begin{array}{c}1.223 \\
(1.225)\end{array}$ \\
\hline $\begin{array}{l}\text { Combinations of } \\
\text { variables }\end{array}$ & & & & & & \\
\hline $\begin{array}{l}\text { Nomination winner } \\
\text { woman }\end{array}$ & $\begin{array}{l}1.410 \\
(0.777)\end{array}$ & $\begin{array}{c}0.774 \\
(1.182)\end{array}$ & $\begin{array}{c}0.400 \\
(1.145)\end{array}$ & $\begin{array}{c}0.952 \\
(1.09)\end{array}$ & $\begin{array}{l}\mathbf{1 5 . 8 8 4} \\
(0.751)\end{array}$ & $\begin{array}{r}-0.296 \\
(1.125)\end{array}$ \\
\hline $\begin{array}{l}\text { Nomination winner } \\
\text { visible minority }\end{array}$ & $\begin{array}{r}-0.469 \\
(1.061)\end{array}$ & $\begin{array}{c}0.943 \\
(1.939)\end{array}$ & $\begin{array}{c}0.517 \\
(1.092)\end{array}$ & $\begin{array}{c}0.841 \\
(1.052)\end{array}$ & $\begin{array}{c}\mathbf{1 7 . 0 9 4} \\
(1.477)\end{array}$ & $\begin{array}{c}1.713 \\
(1.257)\end{array}$ \\
\hline $\begin{array}{l}\text { Nomination winner } \\
\text { incumbent }\end{array}$ & $\begin{array}{l}1.254 \\
(0.834)\end{array}$ & $\begin{array}{r}-0.521 \\
(0.594)\end{array}$ & $\begin{array}{c}0.114 \\
(0.665)\end{array}$ & $\begin{array}{r}-0.635 \\
(0.701)\end{array}$ & $\begin{array}{r}-0.715 \\
(0.499)\end{array}$ & $\begin{array}{c}0.809 \\
(0.512)\end{array}$ \\
\hline $\begin{array}{l}\text { Nomination winner } \\
\text { star candidate }\end{array}$ & $\begin{array}{l}\mathbf{1 5 . 7 4} \\
(1.36)\end{array}$ & $\begin{array}{r}-0.245 \\
(1.744)\end{array}$ & $\begin{array}{c}0.204 \\
(1.111)\end{array}$ & $\begin{array}{r}-0.797 \\
(1.673)\end{array}$ & $\begin{array}{l}\mathbf{2 8 . 5 2 7} \\
(1.653)\end{array}$ & $\begin{array}{c}0.319 \\
(1.245)\end{array}$ \\
\hline Observations & 740 & 740 & 740 & 816 & 816 & 816 \\
\hline
\end{tabular}

Notes: Logistical Regression Models: Coefficients Reported (robust standard errors in parentheses, clustered on each individual Member of Parliament).

Coefficients in bold significant at $5 \%$ or better.

Fixed effects (dummy variables for each election year) included in the model, results omitted.

"Combinations of variables" (in grey) reflect linear combination of appointment status with interacted variables (e.g. appointed ever + appointed*woman) using "lincom" command in STATA, to allow for easier interpretation of interactions. 
(coefficient of -1.433), while past nomination winners are more active: star candidates in this category are more likely to introduce private members' business (coefficient of 15.75).

Patterns of committee work also demonstrate that locally nominated MPs are more likely than parachuted MPs to engage in low-profile legislative activities. We distinguish between MPs who chair House of Commons standing committees and sub-committees, which are generally smaller and have a more specialized focus. Local nominees are more likely than appointed candidates to chair sub-committees (coefficient of 15.573), and are more likely to sit on committees as members (coefficient of 1.655). While there is no significant difference between appointed and locally nominated candidates in terms of chairing parliamentary committees, the findings about sub-committee chairmanships and committee memberships demonstrate that local nominees are more likely to embrace low-profile parliamentary activities. Tellingly, "star candidates" are less likely to engage in low profile activities, either in the form of private members' business or as sub-committee chairs.

Other types of factors, including sex, visible minority status, and incumbency, have very little impact on low-profile activities. Visible minorities are less likely to chair committees, but demographics appear to have little impact on other legislative activities, whether high or low profile. Interestingly, those candidates who had higher vote share in the previous election were more likely to chair committees, perhaps reflecting the perceived importance of this legislative activity.

When we examine the impact of interactions between appointment status and other variables of interest, a few interesting patterns emerge. The lower half of Table 4 presents the linear combination of appointment status with the interaction variables. As for high profile activities, we wanted to explore the possibility that parachute status has a different impact for different types of groups: parachuted women versus men; and parachuted stars versus non-stars, for example, might be involved in different types of legislative activities. The linear combinations of coefficients indicate that there are some important differences across groups of parachuted candidates. Nominated women are more likely than nominated men to sit as sub-committee chairs, as are visible minority nomination winners. Star candidates who won their nomination in the traditional manner (i.e. they were not parachuted in by the leader) were also very active in low-profile pursuits, including private members' business and chairing sub-committees.

We control for cabinet and shadow cabinet status, and as the table indicates, cabinet members, "high-profile" government MPs, are less likely to engage in "low-profile" activities, although shadow cabinet status has no effect. These data suggest that, broadly speaking, pathways to candidacy do have an influence on the legislative activities of MPs: parachuted MPs tend to be rewarded with high profile positions, while traditionally nomination winners tend to be involved more heavily in low profile activities, especially committee work. 


\section{Discussion and Conclusion}

In this article we have examined the legislative roles and activities of Canadian Liberal MPs on the basis of the manner in which they received party nominations. In particular, we asked whether appointed and nominated MPs differ in their legislative activities. We uncover a clear relationship between nomination method and legislative roles and activities. There is a significant difference in the legislative activities of parachuted and nominated MPs. Parachuted MPs are more likely than traditionally-nominated MPs to occupy high-profile parliamentary positions - indeed, they are substantially more likely to sit in cabinet. In contrast, MPs nominated in the traditional manner are more likely to engage in low-profile parliamentary activities such as introducing motions, making statements, and engaging in committee work.

These findings have a number of implications. For some time in Canada and elsewhere, there has been an accumulation of power in party leaders' offices (Savoie, 1999). Candidate appointments have further empowered party leaders by allowing them to bypass local nominations and install preferred individuals as their party candidates. In many ridings, then, the power to nominate candidates has been centralized in the office of the party leader. Furthermore, there is a clear and strong relationship between the manner in which MPs obtain nominations and the subsequent legislative roles they play.

We argue that the ability to appoint candidates has augmented the power of party leaders in a much more substantial manner than has been previously asserted. In the past, party leaders (whether governing or in opposition) have been constrained in the parliamentary organizations they can construct by the parties' decentralized nomination processes. Once in the House of Commons, leaders were forced to work with the representatives they had been given: the MPs that had managed to secure a local nomination and subsequently win election. In other words, party leaders did not have the exclusive right to fill high-profile legislative roles and in so doing shape the public face of the party. On the contrary, leaders shared this power with the constituency associations, which pre-select the pool that the leader draws on to fill highprofile legislative positions. The propensity of leaders to place appointed candidates in high-profile parliamentary positions, however, means that the power of the leader to shape the party's parliamentary organization as well as its public face is substantially augmented by their ability to appoint candidates. It should also be noted that the total number of appointed candidates does not have to be particularly high in order for the party leader's power to shape the parliamentary organization - and thus the public face of the party - to be substantially increased.

The second class of MPs is non-appointed. These MPs now face the task of competing with appointed MPs for a scarce number of high-profile legislative positions. We argue that since these MPs are less likely to receive high-profile positions, they are instead focusing their energies on low-profile legislative activities. Just as representatives in other democratic states tailor their legislative activities to their institutional settings, so too have non-appointed MPs adapted to the new realities of the Liberal Party's parallel nomination system by engaging in low-profile legislative 
activities that they can marshal to demonstrate a record of legislative accomplishment to their constituents.

Finally, this centralization of power in the hands of the party leader cannot be justified simply on the basis of including women and visible minorities in the governing process. Appointed candidates are more likely to be women or visible minorities, so it is reasonable to conclude that party leaders are using the appointment power to create a more diverse, representative House of Commons. However, appointments have not resulted in a higher likelihood that members of these groups will enter high-profile legislative positions, particularly the cabinet. Furthermore, and perhaps more importantly, it is a special sub-group of parachuted candidates that is most likely to be placed in high-profile legislative roles and least likely to engage in low-profile activity: white male parachutees are most likely to be invited to sit in cabinet, especially if they are incumbents. Parachuted women and parachuted visible minority candidates are not more likely to be rewarded with high-profile positions.

As Studlar and Moncrief (1997) point out, high-profile parliamentary positions (particularly in the cabinet), not simply membership in the legislature, are the sources of real power in executive-centered party-disciplined parliamentary systems such as Canada. While it appears that women are more likely to be shielded from nomination battles in the constituencies, party efforts to increase the diversity of the House of Commons stop there. Incumbents, stars, and other parachuted candidates (namely white men) are more likely to be promoted to high profile positions. It appears that inequities continue to exist in the Canadian Parliament and, while parties are making efforts to redress traditional imbalances, parachuting candidates is a solution that only goes so far.

These findings invite application to political parties in other parliamentary democracies, including parties that have retained a strong role for party leaders in selecting candidates (Rahat, 2007: 160). This is particularly true especially to parties that, like the Liberal Party of Canada, employ more than one method of nominating candidates. ${ }^{8}$ Candidate nominations in the British Labour Party, for example, have traditionally been a local responsibility; however, the use of constituency "twinning" and particularly all-women shortlists (AWS) in recent elections has limited this prerogative and, in the latter case, provided leaders and the central party office with a means to directly interfere in the selection process (Cutts et al., 2008). These practices raise some important questions: what motivates party officials to construct the shortlists that they do? And do the legislative roles and behaviors of AWS-nominated candidates differ from those of locally selected candidates? Comparison across democracies would also have the benefit of expanding the present analysis from a cadre or catch-all party to mass-style parties such as UK Labour. Furthermore, the two "paths to parliament" in the Canadian Liberal Party provide extreme examples of centralized (leader appointment) and decentralized (member-nominated) selection processes; an examination of representatives nominated in different ways may yield new findings concerning what we expect is a more nuanced relationship between nomination method and legislative roles. This article focuses on a single party, and 
therefore represents a first step toward a wider analysis of candidate nomination and legislative roles in developed democracies.

\section{Acknowledgments}

We wish to thank Xaiver Campbell, Shawn Kavanagh, Erika Kirkpatrick, and Susan Piercey for providing excellent research assistance. We also wish to thank Kelly Blidook for sharing data with us, as well as David Docherty, Peter Loewen, and this journal's anonymous reviewers for their comments and suggestions. Koop acknowledges financial support from Memorial University of Newfoundland and the Skelton-Clark Foundation at Queen's University.

\section{Notes}

1. "Parachuting" candidates is a somewhat derogatory colloquialism used in Canada to refer to party leaders appointing candidates.

2. The terms "constituency" and "riding" are used interchangeably in Canada.

3. For the 38th Parliament following the 2008 national election, legislative roles and activities were included only for the first session.

4. Data not shown.

5. Independent variables include whether or not the MP was initially parachuted into a riding ("appointed ever"), whether the MP was parachuted in the most recent election, sex, visible minority status, vote share (coded in terciles - bottom third, middle third and top third of all races across all elections), incumbency and "star candidate" status. With the exception of vote share, all independent variables are binary. In addition, a series of interactions were performed between "appointed ever" and other variables of interest: sex, visible minority, incumbent and star candidate, in order to determine whether there were differences across "types" of parachuted candidates. Finally, each logit model controls for fixed effects by including dummy variables for each election year.

6. For the three "high profile" models, Penalized Likelihood Logistical Estimations (PLE) were used, because while no single variable "perfectly" predicted success or failure of the model, a linear combination of variables did, and in a basic logistical model, observations were automatically dropped from the analysis. Zorn suggests that the appropriate solution to this problem is the use of PLE, which forces the statistical program to keep those previously dropped independent variables in the model, thus allowing us to determine the impact of each of the variables. He argues that this approach "prevents researchers from being forced either to omit manifestly important covariates from their models or to engage in post-hoc data manipulation in order to obtain parameter estimates for those covariates" (Zorn, 2005: 166). We therefore used the "firthlogit" package adapted for STATA by Joseph Coveney, available for download at http://ideas.repec.org/c/boc/bocode/s456948.html.

7. Recall, the models presented in Tables 3 and 4 controls for fixed effects by including dummy variables for each election year. In 2006 and 2008, the Liberal Party was in opposition rather than government, thus the models also control for opposition and government status. As is expected, government versus opposition status has an obvious impact on propensity to be placed in cabinet or shadow cabinet: members are only appointed to cabinet if the Liberal Party is in government. The impact of government/opposition status is less important for low-profile activities, although Liberal members tend to sit and chair committees slightly more often when in opposition.

8. There are numerous examples of parties that use more than a single method of selecting candidates or that involve both elites and members in the process. In some Belgian parties, for example, party lists for multi-member districts are prepared by elite party agencies and are subsequently voted on by party 
members (De Winter, 1988). And while party members in Mexico are increasingly selecting district candidates, list candidacies continue to be rewarded by party elites (Wuhs, 2006).

\section{References}

Barrie, Doreen \& Gibbins, Roger (1989) Parliamentary careers in the Canadian Federal State. Canadian Journal of Political Science, XXII(1), pp. 137-145.

Berkman, Michael \& Eisenstein, James (1999) State legislators as congressional candidates: the effects of prior experience on legislative recruitment and fundraising. Political Research Quarterly, 52(3), pp. 481-498.

Blidook, Kelly (2010) Exploring the role of "legislators" in Canada: do members of parliament influence policy?. The Journal of Legislative Studies, 16(1), pp. 32-56.

Carty, R. K. (2002) The politics of Tecumseh Corners: Canadian political parties as franchise organizations. Canadian Journal of Political Science, 35(4), pp. 723-745.

Carty, R. K. \& Eagles, Munroe (2005) Politics is Local: National Politics at the Grassroots (Oxford: Oxford University Press).

Caul, Miki (2001) Political parties and the adoption of candidate gender quotas: a cross-national analysis. Journal of Politics, 63(4), pp. 1214-1229.

Cheng, Christine \& Tavits, Margit (2011) Informal influences in selecting female political candidates. Political Research Quarterly, 64, pp. 460-471.

Cox, Gary W. \& McCubbins, Daniel (1993) Legislative Leviathan: Party Government in the House (Cambridge: Cambridge University Press).

Crisp, Brian F., Escobar-Lemmon, Maria, Jones, Bradford S., Jones, Mark P. \& Taylor-Robinson, Michelle M. (2004) Vote-seeking incentives and legislative representation in six presidential democracies. The Journal of Politics, 66(3), pp. 823-846.

Cross, William (2004) Political Parties (Vancouver: UBC Press).

Cutts, David, Childs, Sarah \& Fieldhouse, Edward (2008) "This is what happens when you don't listen": all-women shortlists at the 2005 general election. Party Politics, 14(5), pp. 575-595.

De Winter, Lieven (1988) Belgium: democracy or oligarchy? in: Michael Gallagher \& Michael Marsh (eds) Candidate Selection in Comparative Perspective: The Secret Garden of Politics (London: Sage), pp. 20-46.

Docherty, David C. (1997) Mr. Smith Goes to Ottawa: Life in the House of Commons (Vancouver: UBC Press).

Eagles, Munroe (2004) The effectiveness of local campaign spending in the 1993 and 1997 federal elections in Canada. Canadian Journal of Political Science, 71(1), pp. 117-136.

Erickson, Lynda (1998) Entry to the commons: parties, recruitment, and the election of women in 1993, in: Manon Tremblay \& Caroline Andrew (eds) Women and Political Representation in Canada (Ottawa: University of Ottawa Press), pp. 219-256.

Hazan, Reuven Y. (1999) Constituency interests without constituencies: the geographical impact of candidate selection on party organization and legislative behavior in the 14th Israeli Knesset, 1996-1999. Political Geography, 18(7), pp. 791-811.

Hix, Simon (2004) Electoral institutions and legislative behavior: explaining voting defection in the European Parliament. World Politics, 56(2), pp. 194-223.

Judge, David \& Ilonszki, Gabriella (1995) Member-constituency linkages in the Hungarian parliament. Legislative Studies Quarterly, 20(2), pp. 161-176.

Kerby, Matthew (2009) Worth the wait: determinants of ministerial appointment in Canada, 1935-2008. Canadian Journal of Political Science, 42(3), pp. 593-611.

Koehn, Miriam (1998) Targeted representation? An analysis of the appointment of Liberal candidates in the 1993 and 1997 federal elections. Past Imperfect, 7, pp. 55-86.

Koop, Royce (2010) Professionalism, sociability, and the Liberal Party in the constituencies. Canadian Journal of Political Science, 43(4), pp. 893-913. 
Lancaster, Thomas \& Patterson, W. David (1990) Comparative pork barrel politics: perceptions from the West German Bundestag. Comparative Political Studies, 22(4), pp. 458-477.

Lundberg, Thomas Carl (2006) Second-class representatives? Mixed-member proportional representation in Britain. Parliamentary Affairs, 59(1), pp. 60-77.

Malloy, Jonathan (2003) High discipline, low cohesion? The uncertain patterns of Canadian parliamentary party groups. The Journal of Legislative Studies, 9(4), pp. 116-129.

Matland, Richard E. \& Studlar, Donley (1996) The contagion of women candidates in single member district and proportional representation electoral systems: Canada and Norway. The Journal of Politics, 58(3), pp. 707-733.

Matland, Richard E. \& Studlar, Donley T. (2004) Determinants of legislative turnover: a cross-national analysis. British Journal of Political Science, 34(1), pp. 87-108.

Mcleay, Elizabeth \& Vowles, Jack (2007) Redefining constituency representation: the roles of New Zealand MPs under MMP. Regional and Federal Studies, 17(1), pp. 71-95.

Michels, Robert (1915) Political Parties (New York: Free Press).

Mishler, William (1978) Nominating attractive candidates for parliament: recruitment to the Canadian House of Commons. Legislative Studies Quarterly, 3(4), pp. 581-599.

Mitchell, Paul (2000) Voters and their representatives: electoral institutions and delegation in parliamentary democracies. European Journal of Political Research, 37(3), pp. 335-351.

Rahat, Gideon (2007) Candidate selection: the choice before the choice. Journal of Democracy, 18(1), pp. 157-170.

Rogers, Norman (1933) Federal influences on the Canadian cabinet. The Canadian Bar Review, 12, pp. $282-301$.

Savoie, Donald J. (1999) Governing from the Centre: The Concentration of Power in Canadian Politics (Toronto: University of Toronto Press).

Sayers, Anthony M. (1999) Parties, Candidates, and Constituency Campaigns in Canadian Elections (Vancouver: UBC Press).

Schattschneider, E. E. (1942) Party Government (New York: Rinehart).

Shepsle, Kenneth A. (1978) The Giant Jigsaw Puzzle: Democratic Committee Assignments in the Modern House (Chicago: University of Chicago Press).

Soroka, Stuart, Penner, Erin \& Blidook, Kelly (2009) Constituency influence in parliament. Canadian Journal of Political Science, 42(3), pp. 563-591.

Strom, Kaare (1997) Rules, reasons and routines: legislative roles in parliamentary democracies, in: Wolfgang C. Muller \& Thomas Saaldfeld (eds) Members of Parliament in Western Europe: Roles and Behavior (London: Frank Cass and Company), pp. 255-274.

Studlar, Donley T. \& Moncrief, Gary F. (1997) The recruitment of women cabinet ministers in the Canadian provinces. Governance, 10(1), pp. 67-81.

Studlar, Donley T., Alexander, Dianne L., Cohen, Joanna E., Ashley, Mary Jane, Ferrence, Roberta G. \& Pollard, John S. (2000) A social and political profile of Canadian legislators, 1996. The Journal of Legislative Studies, 6(2), pp. 93-103.

Tremblay, Manon \& Pelletier, Ŕejean (2001) More women constituency party presidents: a strategy for increasing the number of women candidates in Canada?. Party Politics 7(2), pp. 157-190.

Trimble, Linda \& Arscott, Jane (2003) Still Counting: Women in Politics Across Canada (Toronto: Broadview Press).

White, Graham (2001) Adapting the Westminster model: provincial and territorial cabinets in Canada. Public Money and Management, 21(2), pp. 17-24.

Wuhs, Steven T. (2006) Democratization and the dynamics of candidate selection rule change in Mexico, 1991-2003. Mexican Studies, 22(1), pp. 33-55.

Zorn, Christopher (2005) A solution to separation in binary response models. Political Analysis, 13(2), pp. 157-170. 